https://doi.org/10.46813/2021-135-026

\title{
HIGH RESOLUTION TRANSMISSION ELECTRON MICROSCOPY STUDY OF CRYSTALLOGRAPHY AND MORPHOLOGY OF TiC PRECIPITATES IN ARGON IRRADIATED 18Cr10NiTi STEEL
}

\author{
A.S. Kalchenko, S.A. Karpov, G.D. Tolstolutskaya \\ National Science Center "Kharkov Institute of Physics and Technology”, Kharkiv, Ukraine \\ E-mail: kalchenko@kipt.kharkov.ua
}

This work encompasses identification of the crystal structure and analysis of the TiC precipitates in 18Cr-10Ni-Ti austenitic stainless steel under Ar-ions irradiation. High resolution transmission electron microscopy (HRTEM) and energy dispersive spectroscopy (EDS) are used. Orientation relationship of TiC particles in surrounding matrix are indicated by HRTEM and diffraction patterns. The size of the precipitates is found to be critical: the coherency of $\mathrm{TiC}$ is kept at the interfaces when the precipitate is in the stage of nucleation, whereas the growth of precipitate up to $10 \mathrm{~nm}$ can lead to the loss of coherency in the austenitic steel. The findings suggest that the incoherent precipitate-matrix interface is an important point defect sink and contributes to inert gas bubble formation at elevated irradiation temperatures.

PACS: 52.40Hf, 28.52Fa, 68.49Sf, 79.20Rf

\section{INTRODUCTION}

Generally, the irradiation in most reactors occurs at elevated temperatures. The combined effect of temperature, increased concentration of defects and radiation-induced segregation results in precipitation of second phases in austenitic stainless steels [1, 2]. Various phases have been observed including ferrite, several carbides, borides and phosphides, $\sigma$ (sigma), $\chi$ (chi) and Laves phases, as well as $\mathrm{G}$ and $\eta$ (eta) silicide [3]. It should be noted that several of these phases $\left(\mathrm{M}_{23} \mathrm{C}_{6}, \mathrm{M}_{6} \mathrm{C}\right.$, G-phase) represent fcc structures with similar lattice spacings $(1.06 \ldots 1.1 \mathrm{~nm}$, very close to three times that of the austenite matrix).

The precipitation behaviour of transition-metal carbides, designated as $\mathrm{MX}$, such as $\mathrm{VC}, \mathrm{NbC}$, and $\mathrm{TiC}$, has been extensively investigated in steels for several decades. TiC precipitation in austenitic steels is one of those responsible for the radiation stability of irradiated stainless steels. These precipitates can accelerate point defects recombination at the interfaces, change the ability of dislocations to absorb point defects. Their stability is decisive for the swelling resistance in steels of this type [1].

Regarding to the development of helium porosity, $\mathrm{TiC}$ precipitation due to their greatest positive dimensional mismatch in comparison with the matrix can cause the appearance of a flux of vacancies. A strong vacancy supersaturation of MX-type precipitates in combination with the migration of helium leads to the formation of vacancy cluster - helium bubble complexes on the surface of MX precipitates. The course of these processes depends to a large extent on the coherence of precipitates.

It was shown [4] that argon can be used as an analogue of helium in implantation-and-annealing experiments, provided that the doses are adjusted so that the gas concentrations are equivalent.

Since segregation caused by radiation can modify the composition of the precipitate and the surrounding matrix, the measurement of precipitate lattice constant in the TEM by itself may not be definitive for phase identification. Image processing by Fourier mask filtering in high resolution TEM images is widely employed in producing a contrast enhanced image and is achievable through application of a suitable spatial frequency filter in the Fourier space of a digital electron micrograph [5].

The main focus of this study is to understand the structure and the orientation relationship of the $\mathrm{TiC}$ precipitation with respect to the matrix of $18 \mathrm{Cr} 10 \mathrm{NiTi}$ austenitic stainless steel irradiated with Ar-ions by using high resolution transmission electron microscopy and performing serial processes such as Fast Fourier Transform (FFT), Fourier mask filtering and inverse FFT (IFFT),

\section{MATERIAL AND METHODS}

In this study samples of $18 \mathrm{Cr} 10 \mathrm{NiTi}$ austenitic stainless steel for TEM studies were prepared as disks of $3 \mathrm{~mm}$ in diameter. Thin foils were obtained by mechanical thinning of the disks down to $130 \mu \mathrm{m}$ followed by electropolishing and short-term annealing.

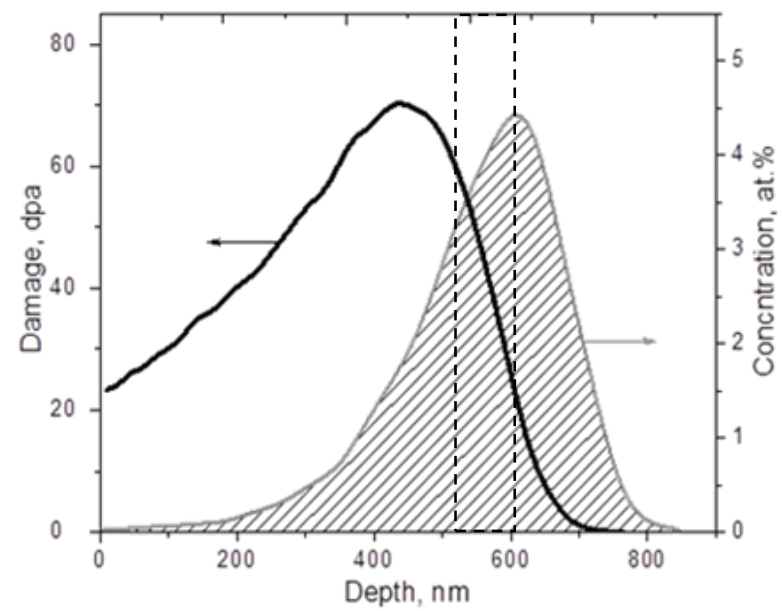

Fig. 1. The depth distribution of damage and concentration of Ar atoms calculated with SRIM for 18Cr1ONiTi irradiated by $1.4 \mathrm{MeV}$ Ar ions to a dose of $1 \cdot 10^{17} \mathrm{~cm}^{-2}$. The dotted lines indicate the analysis area 
Irradiation experiments were conducted in the accelerating-measuring system "ESU-2" [6]. The samples were irradiated with a $1.4 \mathrm{MeV} \mathrm{Ar}^{+}$ion beam at irradiation temperatures of $600{ }^{\circ} \mathrm{C}$. Calculated by SRIM 2008 [7] depth distribution profiles of damage and concentration of $\mathrm{Ar}$ atoms implanted in $18 \mathrm{Cr} 10 \mathrm{NiTi}$ steel to a dose of $1 \cdot 10^{17} \mathrm{~cm}^{-2}$ are shown in Fig. 1.

The damage calculations are based on the KinchinPease model (KP), with a displacement energy for each alloying element was set to $40 \mathrm{eV}$, as recommended in ASTM E521-96 (2009) [8].

To remove a specified depth layer of material from irradiated side of the sample the electro-pulse technique was used and then TEM studies were carried out [9].

Samples were investigated in JEM-2010 microscope. As is known, when the phase information is extended beyond the point resolution of the electron microscope, the phase contrast will not be intuitively coincident with the atomic potential of the specimen [10]. An image does not reflect correctly the atomic structure of the sample; therefore, it is necessary to use a special method for reconstructing the image of the atomic structure of the material. A fairly simple approach is to apply a virtual aperture by applying a Fourier mask filtering technique to the experimental diffractogram, which determines the phase information limit that does not exceed the microscope point resolution.

High resolution TEM images were evaluated using FFT. ImageJ and Digital Micrograph were used for interplanar distances and interplanar angle measurements [11]. Selected area (electron) diffraction (SAD) was performed to obtain the diffraction pattern and to identify crystal structures and examine crystal defects. X-ray EDS equipped with TEM was used to identify the chemical composition of the precipitates. Microstructural and precipitates parameter data were extracted using conventional techniques conducted on JEM-2100 TEM, employing standard bright-field techniques.

\section{RESULTS AND DISCUSSION}

TEM observations of $18 \mathrm{Cr} 10 \mathrm{NiTi}$ steel in the as received conditions indicated three variants of the $\mathrm{TiC}$ precipitates with the sizes that vary from $\sim 150$ to $5 \mathrm{~nm}$ (Fig. 2).
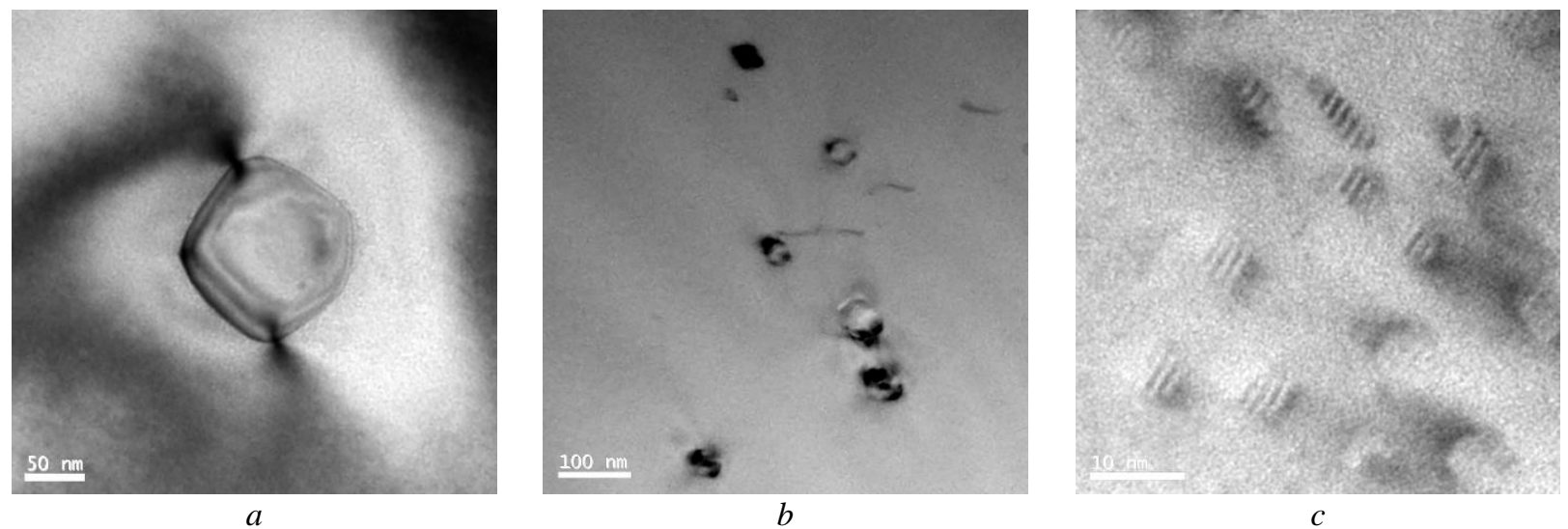

Fig. 2. Precipitates with sizes of $\sim 150(\mathrm{a}), 30(\mathrm{~b})$, and $5 \mathrm{~nm}(\mathrm{c})$ in initial structure of $18 \mathrm{Cr} 10 \mathrm{NiTi}$ steels

Fig. 3 shows TEM micrographs of $18 \mathrm{Cr} 10 \mathrm{NiTi}$ steel samples irradiated with $\mathrm{Ar}^{+}$ions to average dose of $50 \mathrm{dpa}$ at $600{ }^{\circ} \mathrm{C}$. In the depth-layer $500 \ldots 600 \mathrm{~nm}$ from irradiated surface, irradiation-induced argon bubbles were observed in matrix. The average bubble size was determined as $\sim 8 \mathrm{~nm}$; bubbles distribution appears to be almost uniform throughout the material (see Fig. 3,a,b).

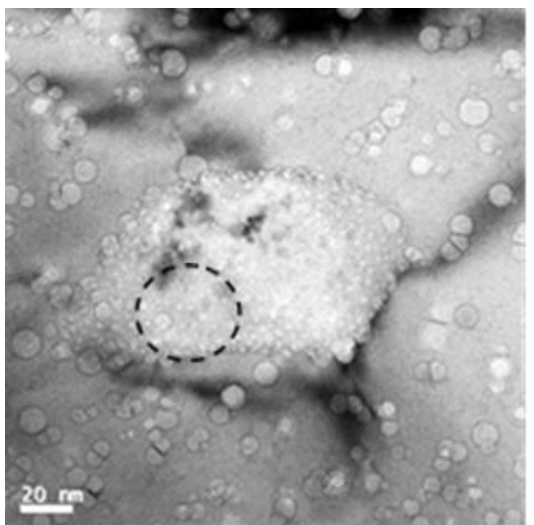

$a$

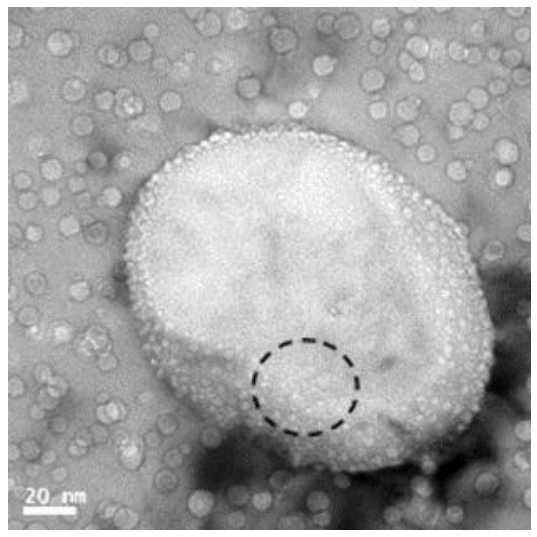

$b$

\section{EDS}

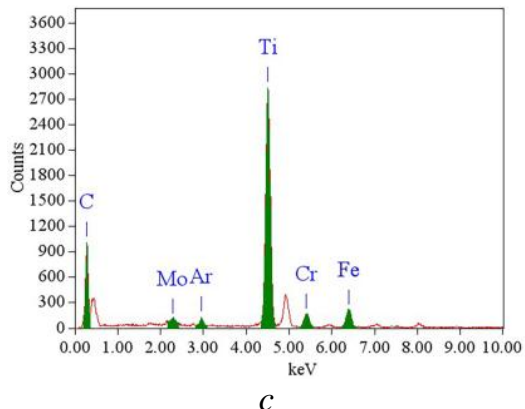

$c$

Fig. 3. Micrographs of the steel under $1.4 \mathrm{MeV} \mathrm{Ar}{ }^{+}$irradiation at $600^{\circ} \mathrm{C}$. Bright-field image showing the precipitate with interfacial argon bubbles and different cut patterns of their surface during electropolishing $(a, b)$. $X$-ray EDS of precipitates $\mathrm{TiC}(\mathrm{c})$. Dotted circle - analysis area 
In turn, large precipitates of about $150 \mathrm{~nm}$ in size with different cut patterns of their surface during electropolishing after argon ion irradiation is covered with bubbles about $2 \mathrm{~nm}$ in size. The precipitates have the composition $\mathrm{TiC}$ with a small amount of molybdenum (see Fig 3,c). Argon is registered in the spectrum recorded from the surface of the precipitates. This allows the small bubbles to be identified as argon ones. The observed density of these small bubbles was high enough to completely cover the surface of the precipitate with one layer (see Fig. 3,b). To determine the mechanism of this phenomenon, it is first necessary to examine the microstructure of precipitates before irradiation and define their degree of coherence.
Fig. 4,a,b shows bright-field image of large precipitate and electron diffraction pattern from it and surrounding matrix. Dark-field image of the precipitate and its EDS is presented in Fig. 4,c,d, respectively. Chemical composition corresponds to $\mathrm{TiC}$ precipitate. Fig. 4,e,g shows High Resolution TEM (HRTEM) observations at the interface of $\mathrm{TiC}$ precipitate in the austenitic matrix.

To examine the lattice match between the precipitate and the austenitic matrix the FFT was applied (see Fig. 4,f) and noise of the lattice was filtered out. Thereafter, an inverse FFT was performed (see Fig. 4,h,i).

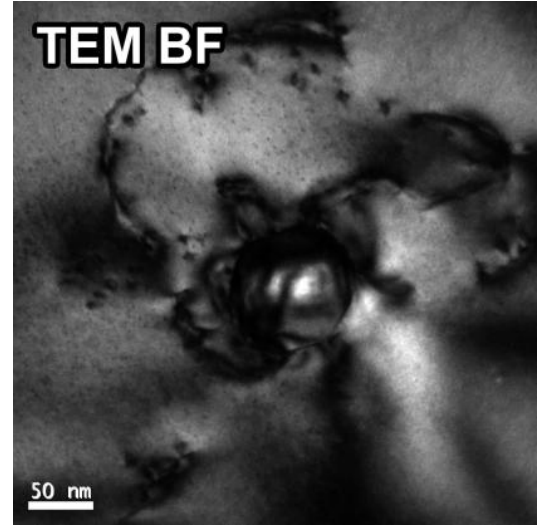

$a$

\section{EDS}

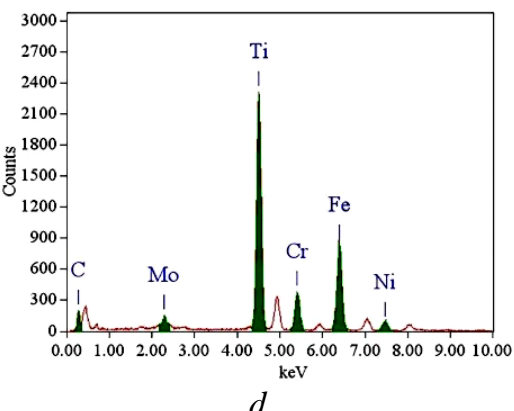

$d$

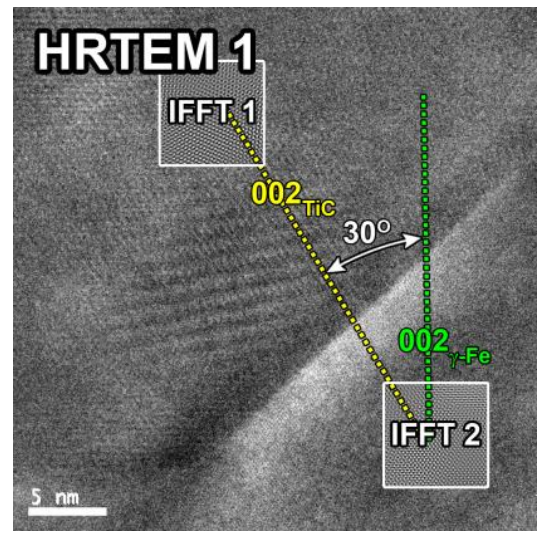

$g$

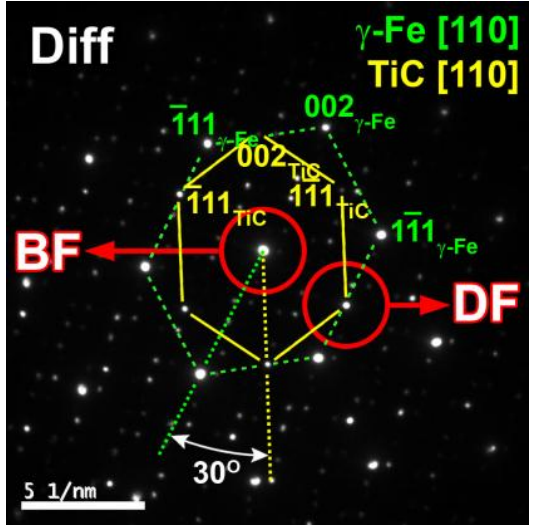

$b$

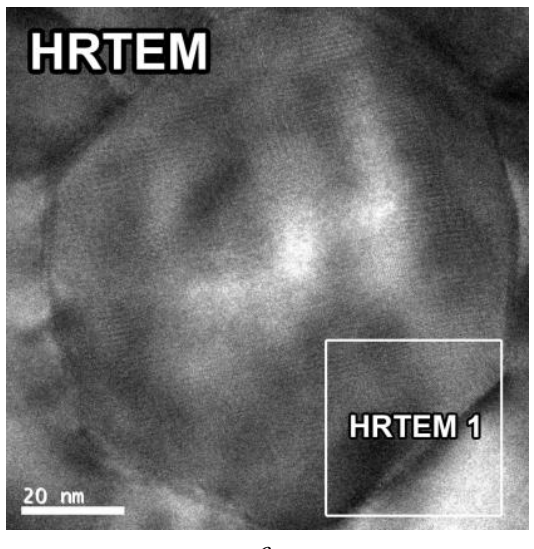

$e$

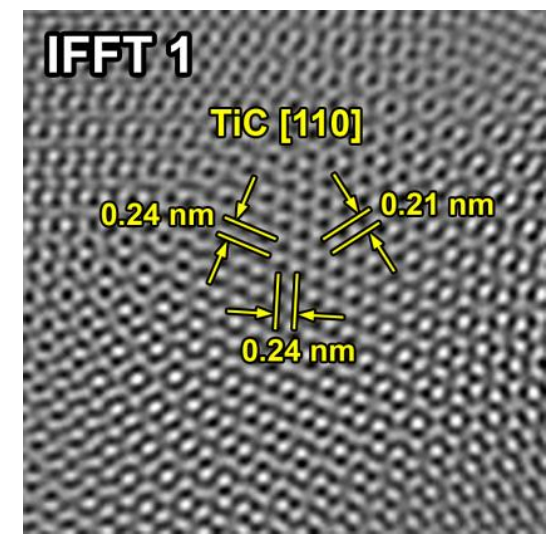

$h$

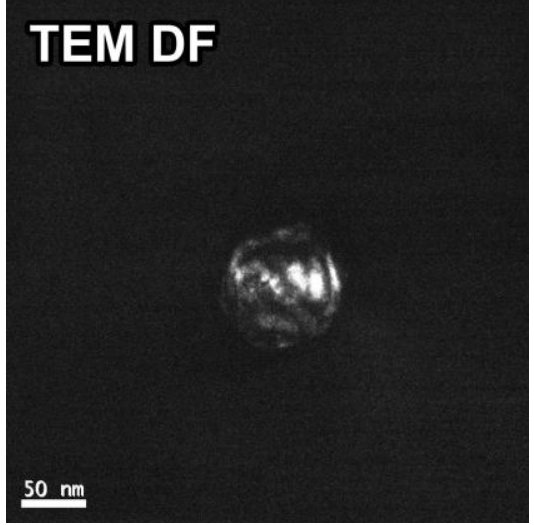

$c$

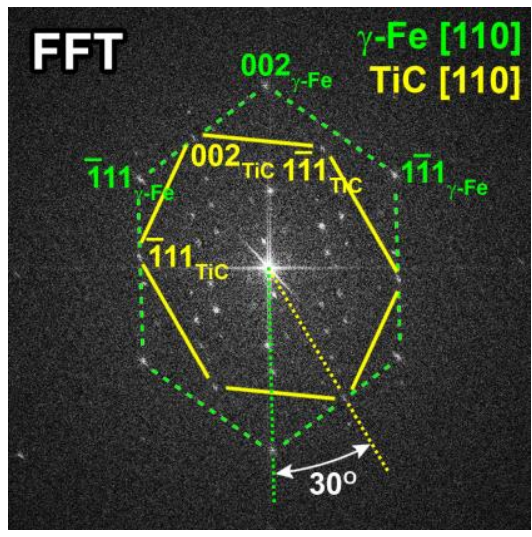

$f$

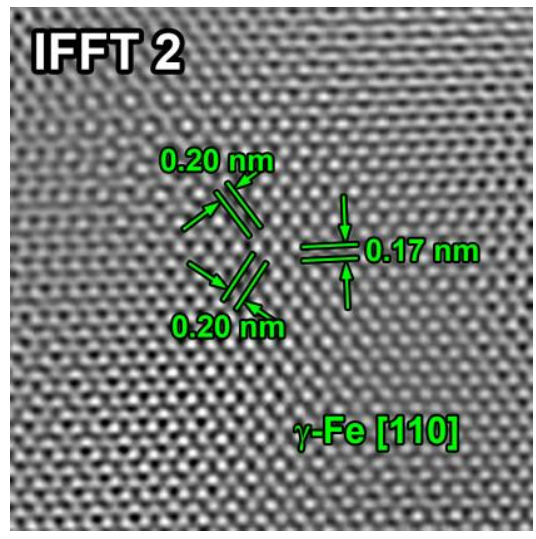

$i$

Fig. 4. Bright-field image showing the TiC precipitate (a); an electron diffraction pattern from TiC particle and matrix (b); dark-field image of the TiC precipitates (c); EDS of precipitate (d); HRTEM image (e) and FFT image obtained from HRTEM (f); high magnification of precipitate-matrix boundary ( $g$ ); inverse IFFT images corresponding to $\mathrm{TiC}(h)$ and the matrix $(i)$ 
Fourier transforms allow to identify the periodic component of images, so they are often used for image analysis and filtering. The consequence of a Fourier transform on a real image is a complex image that is symmetrical around the center. Masking is usually performed with the following sequence - the Fourier transform on the image in real space, mask off the desired frequencies in the frequency space, followed by the inverse Fourier transform on the masked image [11]. Both TiC phase and $\gamma$-Fe matrix had zone axis [110] according to FFT, IFFT, and diffraction patterns.

Interplanar distances of $\mathrm{TiC}$ are $\mathrm{d}_{111}=$ $(0.24 \pm 0.01) \mathrm{nm}$ and $\mathrm{d}_{200}=(0.21 \pm 0.01) \mathrm{nm}$. Interplanar distances of $\gamma$-Fe matrix are $\mathrm{d}_{111}=(0.20 \pm 0.01) \mathrm{nm}$ and $\mathrm{d}_{200}=(0.17 \pm 0.01) \mathrm{nm}$. The TiC precipitate and matrix lattices are rotated by $30^{\circ}$ (see Fig. 4,b,f). The deviation of $\mathrm{TiC}$ orientation from matrix by more than $5^{\circ}$, its dark contrast in $\mathrm{BF}$ and $\mathrm{DF}$ images indicate the incoherence of the interface [12].

It should be borne in mind that a coherent interface arises when two crystals match perfectly at the interface plane so that the two lattices are continuous across the interface. This can only be achieved if, disregarding chemical species, the interfacial plane has the same atomic configuration (orientation, interplane distance) in both phases, and this requires the two crystals to be oriented relative to each other in a special way.

The strains associated with a coherent interface raise the total energy of the system, and for sufficiently large atomic misfit, or interfacial area, it becomes energetically more favorable to replace the coherent interface with a semicoherent interface in which the disregistry is periodically taken up by misfit dislocations.

When the interface plane has a very different atomic configuration in the two adjacent phases, there is no possibility of good matching across the interface. The pattern of atoms may either be very different in the two phases or, if it is similar, the interatomic distances may differ by more than $25 \%$. In both cases the interface is defined as incoherent [12].

Thus, for a large precipitate, the elastic energy is a major contributing factor since it is volumetric, which facilitates the evolution of the precipitate towards incoherence in order to reduce the free energy. Contrary, in the case of small precipitate, the elastic energy is not important and the precipitate remains in the coherent state [13].

A very fine precipitate which has a well-defined orientation relationship with the matrix produces a moiré pattern readily when it is embedded in the matrix.

Fig. 5 shows a typical $\mathrm{TiC}$ morphology in the presence of moiré fringes. The moiré fringes appearing at the precipitate are the product of the interference of the [110] TiC and the [110] austenitic $\gamma$-Fe reflection in terms of their spacing and orientation. HRTEM images indicate that atomic planes of matrix and the particles are well aligned. In this case, when the precipitates are coherently combined with the matrix, argon bubbles do not grow on them (see Fig. 5,a).

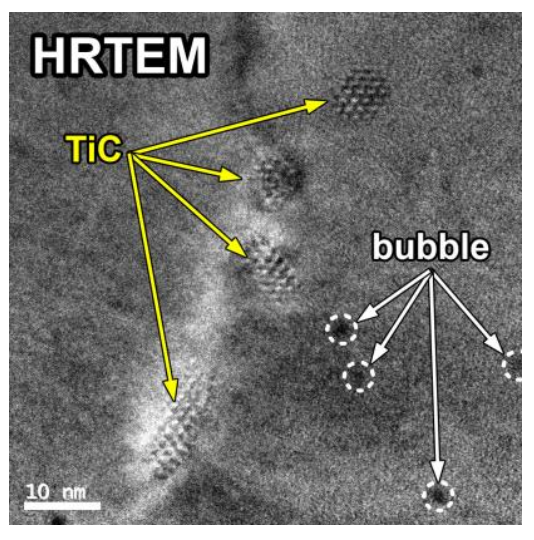

a

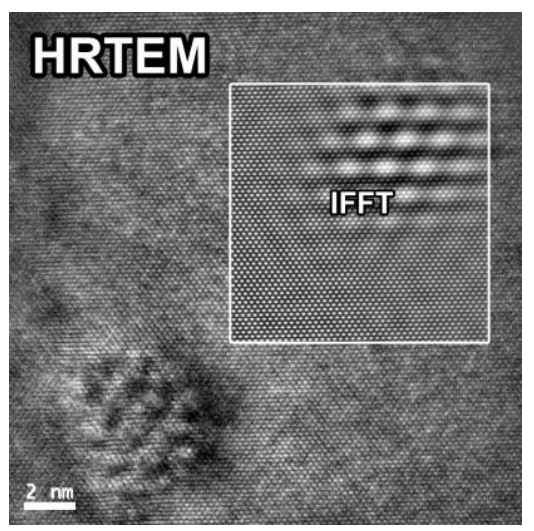

$d$
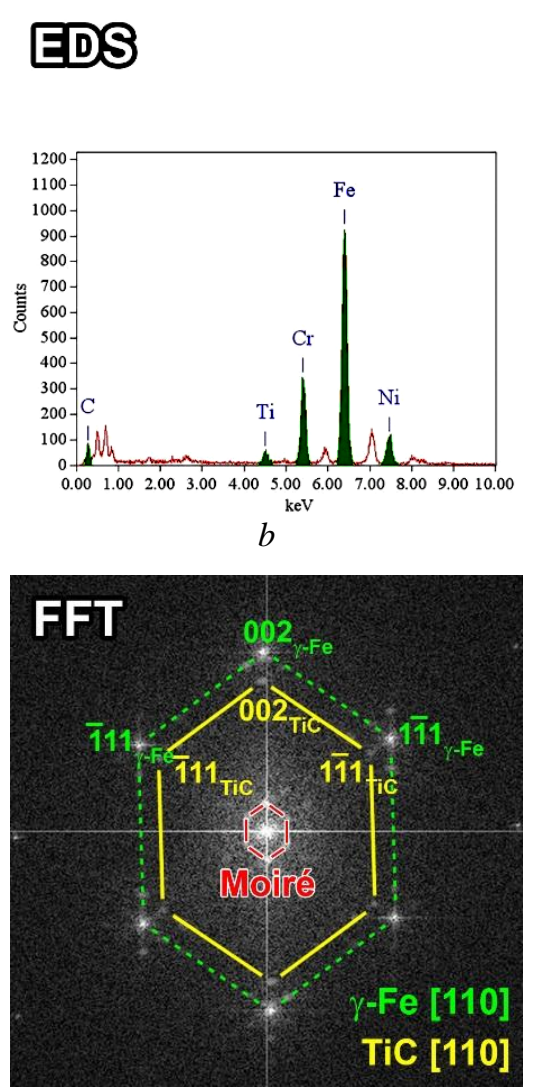

e

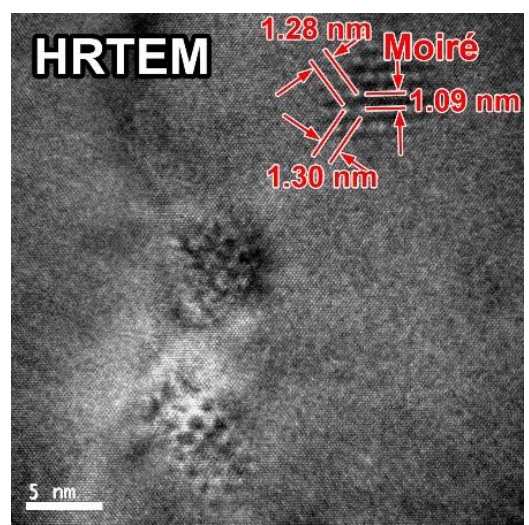

c

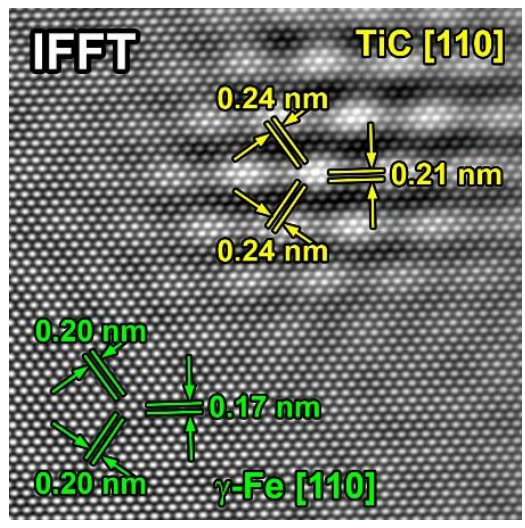

$f$

Fig. 5. HRTEM image of TiC precipitates with the sizes $\sim 10 \mathrm{~nm}$ and bubbles $(a)$; EDS of precipitate $(b)$; HRTEM image of moiré fringes of TiC in matrix (c); HRTEM image with IFFT area (d); FFT image obtained from $\operatorname{HRTEM}(e)$, and IFFT images corresponding to TiC and the matrix $(f)$ 
Theoretical calculated and experimental measured interplanar distances and moiré fringes for $\gamma$-Fe and TiC

\begin{tabular}{|c|c|c|}
\hline Phase & Calculated, $\mathrm{nm}$ & Measured, $\mathrm{nm}$ \\
\hline \multicolumn{3}{|c|}{ Interplanar distance for $\gamma-\mathrm{Fe}$ (fcc structure, lattice parameter $a=0.36 \mathrm{~nm}$ ) } \\
\hline$\gamma$-Fe [111] & 0.21 & $0.19 \ldots 0.21$ \\
\hline$\gamma-\mathrm{Fe}[200]$ & 0.18 & $0.16 \ldots 0.18$ \\
\hline \multicolumn{3}{|c|}{ Interplanar distance for $\mathrm{TiC}$ (fcc structure, lattice parameter $a=0.43 \mathrm{~nm}$ ) } \\
\hline $\mathrm{TiC}[111]$ & 0.25 & $0.23 \ldots 0.25$ \\
\hline $\mathrm{TiC}[200]$ & 0.22 & $0.20 \ldots 0.22$ \\
\hline \multicolumn{3}{|c|}{ Moiré fringe } \\
\hline$\gamma-\mathrm{Fe}[111] \& \mathrm{TiC}[111], 0^{\circ}$ & 1.28 & $1.28 \ldots 1.36$ \\
\hline$\gamma-\mathrm{Fe}[200] \& \mathrm{TiC}[200], 0^{\circ}$ & 1.11 & $1.07 \ldots 1.16$ \\
\hline
\end{tabular}

Interplanar distances were measured from HRTEM images. Table shows theoretically calculated and experimentally measured interplanar distances and moiré fringes for $\gamma$-Fe and $\mathrm{TiC}$ in Figs. 4, 5. The experimentally measured interplanar distances and moiré fringes are in very good agreement with the theoretical values for $\gamma$-Fe and TiC along [110] zone axis.

Large TiC particles apparently accumulate a lot of argon generated in the surrounding matrix during irradiation to form a fine and concentrated dispersion of bubbles at or near the interface.

The susceptibility of $\mathrm{TiC}$ precipitates to trap argon atoms appears to be associated with the size of the precipitates. The coherency of $\mathrm{TiC}$ is kept at the interfaces when the precipitate is in the stage of nucleation. The growth of precipitate can lead to the loss of coherency when the inclusion size (L) is larger than a critical value (Lc). For example, Wei et al. suggested a critical size of $7 \mathrm{~nm}$ for transition from a coherent interface to a semi-coherent interface of a TiC carbide in ferrite [14].

The large positive discrepancy between this precipitation in comparison with the matrix causes the appearance of a flux of vacancies, stabilizing the complex of the vacancy-TiC precipitation that grows during irradiation. A strong vacancy supersaturation near precipitates of the MC type in combination with the migration of argon in a complex with vacancies leads to the formation of argon bubbles on the surface of TiC precipitates (see Fig. 3).

A decrease in the concentration of vacancies in the matrix adjacent to the MC precipitates, together with the accumulation of argon, should support the processes of nucleation of many small pores and the redistribution of fluxes of point defects to these sinks.

Careful examination of precipitation process and matrix relation with particles would help to improve the basic austenitic steels. According to [15], the lattice coherency of the particles with the surrounding matrix is important for strengthening mechanisms. On the other hand, the observed trapping of helium or argon at the interfaces of precipitation suggests that these particles may be able to reduce high-temperature helium embrittlement.

\section{CONCLUSIONS}

In the present study, we applied the methods of HRTEM FFT, Fourier mask filtering and inverse FFT (IFFT) to investigate the structure and the orientation relationship of $\mathrm{TiC}$ precipitation with respect to the matrix of $18 \mathrm{Cr} 10 \mathrm{NiT}$ austenitic stainless steel and to understand the role of precipitates in the behavior of gas bubbles under irradiation with Ar-ions.

It has been established that the size of the precipitates is critical. The coherency of $\mathrm{TiC}$ is kept at the interfaces when the precipitate is in the stage of nucleation. The growth of precipitate can lead to the loss of coherency when the precipitate size is larger than $10 \mathrm{~nm}$ in the austenitic steel.

The large positive discrepancy between this precipitation in comparison with the matrix causes to form a fine and concentrated dispersion of bubbles at or near the interface precipitates - matrix under argon irradiation.

\section{ACKNOWLEDGEMENTS}

The work was financially supported by the National Academy of Science of Ukraine (program "Fundamental scientific research on the most important problems of the development of scientific and technical, socio-economic, socio-political, human potential to ensure Ukraine's competitiveness in the world and sustainable development of society and the state").

\section{REFERENCES}

1. V.N. Voyevodin and I.M. Neklyudov. Evolution of the Structural-Phase State and Radiation Resistance of Structural Materials. Kiev: "Naukova dumka", 2006.

2. J. Malaplate, B. Michaut, A. Renault-Laborne, T. Jourdan, F. Dalle, J. Ribis, B. Radiguet, F. Sefta, B. Décamps. Characterization of ion irradiated microstructure and cavity swelling evolution up to high doses in austenitic stainless steels representative of PWR internals // J. Nucl. Mater. 2019, v. 517, p. 201213. 
3. E.A. Kenik, J.T. Busby. Radiation-induced degradation of stainless steel light water reactor internals // Mat. Sci. and Eng. 2012, R 73, p. 67-83.

4. G.D. Tolstolutskaya, S.A. Karpov, A.S. Kalchenko, I.E. Kopanets, A.V. Nikitin, and V.N. Voyevodin. Effect of argon-ion irradiation on cavity formation and evolution in $18 \mathrm{Cr} 10 \mathrm{NiTi}$ austenitic steel // Problems of Atomic Science and Technology. Series "Physics of Radiation Effect and Radiation Materials Science”. 2020, N 2(126), p. 27-32.

5. J.C.H. Spence. High-resolution Electron Microscopy / 3rd ed. Oxford University Press, New York, 2003, p. 49.

6. G.D. Tolstolutskaya, V.V. Ruzhytskiy, I.E. Kopanetz, V.N. Voyevodin, A.V. Nikitin, S.A. Karpov, A.A. Makienko, T.M. Slusarenko. Accelerating complex for study of helium and hydrogen behavior in conditions of radiation defects generation // Problems of Atomic Science and Technology. Series "Physics of Radiation Effect and Radiation Materials Science". 2010, N 1, p. 135-140.

7. http://www.srim.org/

8. ASTM E521-96, 2009, ASTM.

9. M. Klinger. More features, more tools, more CrysTBox // Journal of Applied Crystallography. 2017, v. 50, p. 1-9.

10. Young-Min Kim, Jong-Man Jeong, Jin-Gyu Kim and Youn-Joong Kim. Image Processing of Atomic Resolution Transmission Electron Microscope Images //
Journal of the Korean Physical Society. 2006, v. 48, N 2, p. 250-255.

11. DM: Digital Micrograph version 3.0 manufactured by Gatan. The demonstration program can be downloaded at www.gatan.com and provide full functions except for saving the data.

12. Wen-Zheng Zhang. Reproducible Orientation Relationships Developed from Phase Transformations Role of Interfaces // Crystals. 2020, v. 10, p. 1042; doi:10.3390/cryst10111042.

13. Fu-Gao Weiy, Toru Hara, and Kaneaki Tsuzaki. High-resolution transmission electron microscopy study of crystallography and morphology of TiC precipitates in tempered steel // Philosophical Magazine. 2004, v. 84 , N 17, p. $1735-1751$.

14. F.-G. Wei, T. Hara, T. Tsuchida, K. Tsuzaki. Hydrogen Trapping in Quenched and Tempered 0.42C-0.30Ti Steel Containing Bimodally Dispersed TiC Particles // ISIJ International. 2003, v. 43(4), p. 539-547.

15. E. Aydogan, J.S. Weaver, U. Carvajal-Nunez, M.M. Schneider, J.G. Gigax, D.L. Krumwiede, P. Hosemann, T.A. Saleh, N.A. Mara, D.T. Hoelzer, B. Hilton, S.A. Maloy. Response of 14YWT alloys under neutron irradiation: a complementary study on microstructure and mechanical properties // Acta Mater. 2019, v. 167, p. 181-196.

\title{
ИССЛЕДОВАНИЕ КРИСТАЛЛОГРАФИИ И МОРФОЛОГИИ ТіС-ПРЕЦИПИТАТОВ В ОБЛУЧЕННОЙ АРГОНОМ СТАЛИ Х18Н10Т С ПОМОЩЬЮ ЭЛЕКТРОННОЙ МИКРОСКОПИИ ВЫСОКОГО РАЗРЕШЕНИЯ
}

\author{
А.С. Кальченко, С.А. Карпов, Г.Д. Толстолуцкая
}

Проведены идентификация кристаллической структуры и анализ выделений ТіС в аустенитной нержавеющей стали X18H10T при облучении ионами Ar. Используются просвечивающая электронная микроскопия высокого разрешения (ПЭМВР) и энергодисперсионная спектроскопия (ЭДС). Ориентационные отношения частиц $\mathrm{TiC}$ в окружающей матрице показаны с помощью ПЭМВР и дифрактограмм. Установлено, что размер выделений критичен: когерентность ТіС сохраняется на границах раздела, когда выделение находится на стадии зарождения, тогда как рост выделения до 10 нм может привести к потере когерентности в аустенитной стали. Полученные данные свидетельствуют о том, что некогерентная граница раздела выделение-матрица является важным стоком точечных дефектов и способствует образованию пузырьков инертного газа при повышенных температурах облучения.

\section{ДОСЛІДЖЕННЯ КРИСТАЛОГРАФІЇ ТА МОРФОЛОГІЇ ТіС-ПРЕЦИПІТАТІВ В ОПРОМІНЕНІЙ АРГОНОМ СТАЛ Х18Н10Т ЗА ДОПОМОГОЮ ЕЛЕКТРОННОЇ МІКРОСКОПІї 3 ВИСОКОЮ РОЗДІЛЬНОЮ ЗДАТНІСТЮ}

\author{
О.С. Кальченко, С.О. Карпов, Г.Д. Толстолуцька
}

Проведено ідентифікацію кристалічної структури та аналіз виділень ТіС в аустенітній нержавіючій сталі $\mathrm{X} 18 \mathrm{H} 10 \mathrm{~T}$ під опроміненням іонами Ar. Використовуються трансмісійна електронна мікроскопія 3 високою роздільною здатністю (ТЕМВРЗ) та енергодисперсійна спектроскопія (ЕДС). Орієнтаційна залежність часток ТіС у навколишній матриці вказується ТЕМВРЗ та дифракційними картинами. Встановлено, що розмір виділень $є$ критичним: когерентність ТіС зберігається на межах розділу, коли виділення знаходиться на стадії зародження, тоді як зростання виділення до 10 нм може призвести до втрати когерентності в аустенітній сталі. Висновки свідчать про те, що некогерентна межа розділу виділення-матриця $є$ важливим стоком точкових дефектів і сприяє утворенню бульбашок інертного газу при підвищених температурах опромінення. 